Jim Skea, Stefan Lechtenböhmer, Jusen Asuka

\title{
Climate policies after Fukushima: three views
}

Originally published as:

Jim Skea, Stefan Lechtenböhmer, Jusen Asuka (2013):

Climate policies after Fukushima: three views

In: Climate Policy, vol. 13, suppl. 1, pp. 36-54

DOI: $10.1080 / 14693062.2013 .756670$ 


\section{Climate policies after Fukushima: three views}

Jim Skea, (Imperial College London, UK)

Stefan Lechtenböhmer (Wuppertal Institute, Germany)

Jusen Asuka (University of Tohoku, Japan) 


\title{
Climate policies after Fukushima: three views
}

\author{
Paper accepted by Climate Policy \\ Special Issue: Low Carbon Drivers for a Sustainable World
}

\begin{abstract}
The 2011 Japanese earthquake and tsunami and the consequent accident at the Fukushima nuclear power plant have had consequences far beyond Japan itself. This paper examines reactions to the accident in three major economies: Japan, the UK and Germany. Each had been committed to relatively ambitious climate change targets prior to the accident. In Japan and Germany, the accident has precipitated a major change of policy direction. In the UK, debate has been muted and there has been essentially no change in energy or climate change policies. For each country, the status of energy and climate change policies prior to the accident is assessed, responses to the accident are described and the possible impact on the country's position in international climate negotiations is analysed. In the final section of the paper, the countries' responses are compared and contrasted, reasons for the different policy responses are suggested and some themes, common across all countries, are identified.
\end{abstract}

\section{Policy Abstract}

The attraction of nuclear power has rested on the promise of low cost electricity, low-carbon energy supply and enhanced energy independence. The Fukushima accident which followed the Japanese tsunami of March 2011 has prompted a critical re-appraisal of nuclear power. This paper assesses the responses to Fukushima in three countries: the UK, Germany and Japan itself. All three countries had foreseen nuclear as playing a significant part in climate mitigation strategies prior to the accident. The UK government has continued to support nuclear new build following a prompt review of safety arrangements. Japan and Germany have decided to phase out nuclear power, albeit on different timescales. The paper systematically assesses the factors that explain the different decisions including patterns of energy demand and supply, the wider political context, institutional arrangements and public attitudes to risk. The implications for international climate negotiations are assessed.

\section{Keywords:}

Climate change mitigation; energy policy; nuclear power; renewable energy 


\section{Introduction}

Prior to the Fukushima accident, Japan, Germany and the UK were committed to relatively ambitious greenhouse gas (GHG) emission reduction targets. All three governments considered nuclear energy to have a role to play in providing low carbon electricity. Japan wanted to boost nuclear generation to 50 or $60 \%$ of all electricity by 2030 under its Basic Energy Plan (METI, 2010). The UK government was committed to a programme of nuclear new build, the last nuclear plant having been commissioned in 1995. Five months before the accident, the German government had reversed a long standing decision on nuclear phase out and had added 196 years to the remaining 67 operating years allowed at the 17 commercial German nuclear power plants (NPPs). This decision was taken in the context of a long term low carbon roadmap (Rossnagel and Hentschel 2010, Jahn, Korolczuck, 2012, 160ff).

The magnitude 9.0 earthquake that devastated the eastern coast of Honshu caused a station blackout at the Daiichi/Fukushima NPP and triggered a huge tsunami leading to a major nuclear accident. In the following weeks, parts of Japan were affected by nuclear fallout (measured in terms of caesium-137) that amounted to about one third of that released after the 1986 Chernobyl accident (Stohl et al, 2011). Concerns about wider nuclear safety and severe common mode failure led to the shutdown of other NPPs resulting in severe shortages of power supply capacity in Japan.

In response to the accident, the UK commissioned a review of the implications of the Fukushima accident for existing and new reactors. The review interpreted the accident as being the result of a singular event extremely unlikely to occur in Northern Europe, combined with inadequate safety specifications. The UK consequently decided to continue with nuclear new build while making relatively minor modifications to regulatory arrangements. However, Germany interpreted the accident as the writing on the wall for nuclear, reversed the decision to extend the lives of its nuclear reactors and accelerated a nuclear phase out, immediately closing down eight of its 17 operating reactors. In the short term, Japan was forced to safeguard electricity supplies with significantly reduced nuclear output and started a fundamental review of policy on electricity generation. In September 2012, Japan followed Germany by planning a nuclear phase-out, though on a longer time timescale with all NPPs due to close in the 2030s.

In this paper, views on the impact of Fukushima on climate and energy policies in the three countries are presented with the aims of explaining the differences in response and understanding better how governments plan to shape their energy systems to achieve low carbon electricity supply. 
To underpin the explanation of the differences, we assess each country individually, focusing on four areas: a) the structure of energy demand and supply; b) energy and climate policies and the wider political context; c) institutional arrangements and economic and environmental regulation of the energy sector; and d) public attitudes to risk, especially those relating to nuclear, and the role of NGOs. Some tentative conclusions about the implications for the country's position in the international arena are then drawn. In the final section responses in the three countries are compared and contrasted with a view to enabling mutual learning for a sustainable low carbon future.

\section{Underlying comparisons: energy markets and risk perception}

The situation regarding patterns of energy supply and demand in the three countries, and drivers of risk perception, are first examined. Figure 1 shows that Japan has the highest absolute level of energy consumption, but in 2009 met less than $20 \%$ of its energy needs through domestic supply. Almost all of this was in the form of nuclear power supplemented by small amounts of bioenergy. The UK, with the smallest level of consumption, was at the opposite end of the spectrum. It met $80 \%$ of its needs through domestic supply though nuclear accounted for only $11 \%$ of that. The UK still produces considerable quantities of oil and gas in the North Sea, but production is declining and the UK's degree of self-sufficiency is projected to fall (DECC, 2010). As the UK is highly dependent on natural gas for electricity generation (40\% in 2011, DECC (2012)), the security of supply question is more acute than Figure 1 suggests. Germany has an intermediate position, meeting $40 \%$ of its energy needs from domestic supply, with nuclear accounting for $12 \%$ of total needs in 2009 . Germany depends almost entirely on imports of oil and natural gas and now imports almost $40 \%$ of its coal.

The contrasts are striking. Viewing this through a security of supply lens, Japan appears to have the greatest "need" for nuclear power while at the other end of the spectrum the UK has less nuclear dependence and less objective need for it. Yet, the UK is the only country of the three with an unambiguous public policy commitment to nuclear new build. 
Figure 1: Primary Energy Demand and Domestic Production 2009

Primary energy demand and domestic production 2009

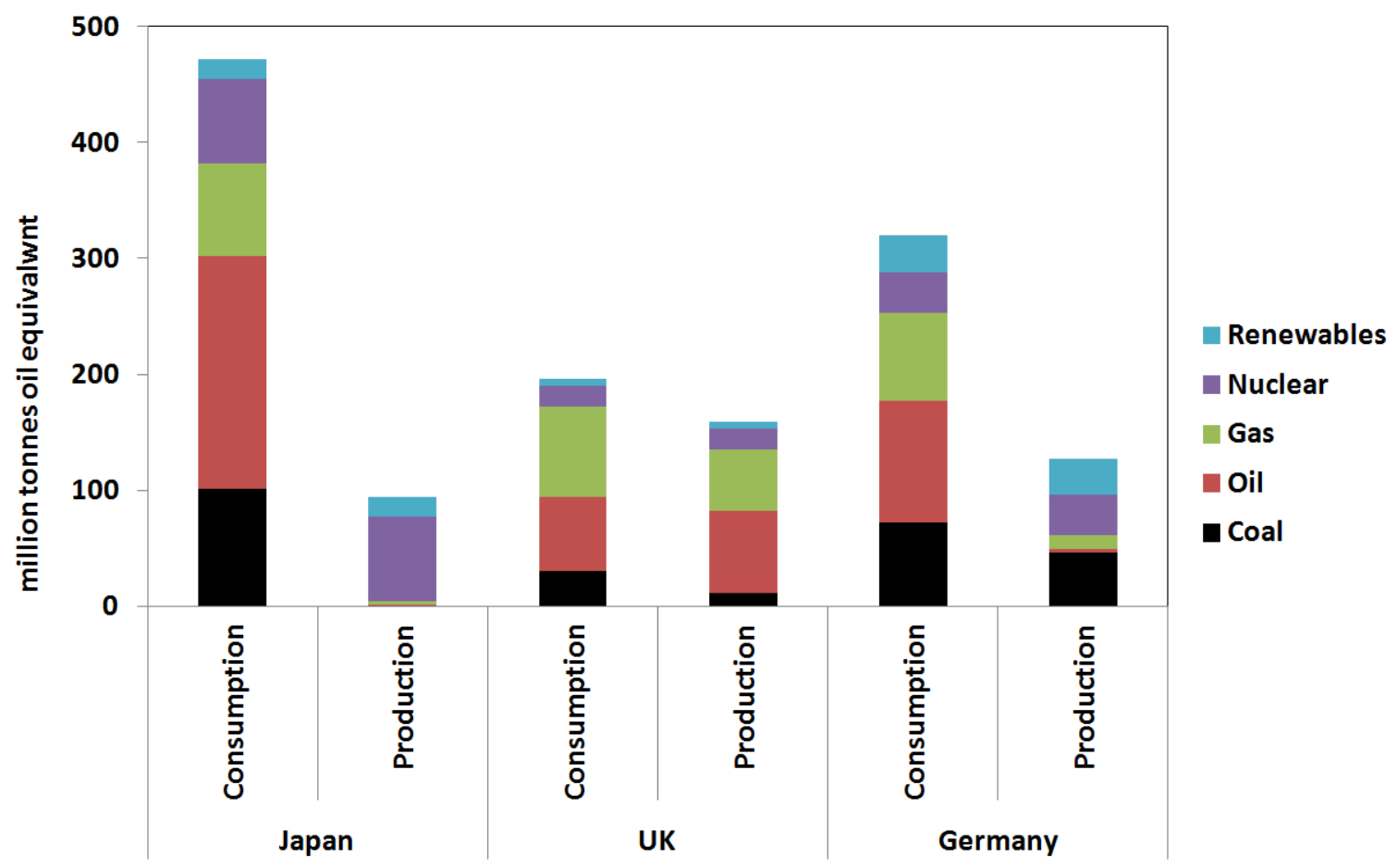

Note: \% electricity from nuclear in 2009: Japan (30\%); UK (21\%); Germany (27\%)

Source: based on International Energy Agency, 2012

Although there is a substantial literature relevant to risk perceptions of nuclear power in and across countries, no study has systematically addressed differences between Japan, Germany and the UK. Country-specific insights from the literature are referred to in the following sections. However, robust generic conclusions have been reached about attitudes to the risks associated with nuclear power. It has been established that "opposition to nuclear energy stems from concerns which go beyond technologies to the social and political institutions they imply. These concerns include the centralisation of scarce and vital resources (such as energy), their control by ever-larger and impersonal bureaucracies, and the growing dependence on the specialised knowledge of technocratic elites.... further, it is related technically and psychologically to nuclear weapons" (Otway et al., 1978). Therefore, the nature of the institutions that control nuclear power and historical associations with nuclear weapons are relevant to the cross-country comparison. 


\section{Energy and Climate Policy in Japan after the Fukushima Nuclear Accident}

\section{Patterns of energy supply and demand in Japan}

Japan is dependent on imports for more than $80 \%$ of its energy needs. Nuclear power has accounted for almost all of Japan's indigenous energy production and has, so far, represented the only means of mitigating import dependence. Prior to the Fukushima accident on 11 March 2011, nuclear accounted for around 30\% of Japan's electricity production. According to the Basic Plan for Energy agreed by the Cabinet in June 2010 (METI, 2010), nine new nuclear power units were planned to be built by 2020 .

The Fukushima accident placed Japan in an acute dilemma, with anxiety about the risks associated with nuclear balanced against the contribution it makes to the energy mix and the need to purchase alternative sources of energy, mainly natural gas and coal, in international markets.

\section{Japanese energy and climate policy}

Pre-Fukushima, the promotion of nuclear power had a relatively-high priority in energy policy. By comparison, decentralised renewable energy and energy conservation had a much lower priority. For example, the government started to promote renewable energy in 2003 through a Renewable Portfolio Standard (RPS) with the utility companies being required to meet very limited purchase quotas. Even if the utility companies were to fulfil their obligations under this RPS, renewable energy would have accounted for only $1.35 \%$ of total electricity consumption by 2012 (METI 2006).

There are three main reasons for this: 1) the government was confident in nuclear power and the strength of Japanese technology, seeing it as a potential export opportunity (ten Hoedt, 2012); 2) the government had focused mainly on the cost of power production without considering wider risks; and 3) power companies have criticised the modifications to existing power grids needed to support decentralised renewable energy as being costly and destabilising to the system.

Although it is neither a formally declared nor a publicly-debated policy, it has also been speculated that one of the reasons for the promotion of the nuclear power generation is to maintain the capacity to have a nuclear deterrent force. In December 2011, Ishiba Shigeru, a former Defence Minister, stirred a public debate by openly mentioning the issue (Wall Street Journal 2011). 
Under these circumstances, there had been little pressure on policy makers to promote renewable energy widely until the Fukushima accident.

\section{Institutional Arrangements}

In Japan, utilities such as Tokyo Electric Power Company (TEPCO) are vertically integrated regional monopolies. The utilities have had little incentive to promote conservation because profits are coupled to the level of electricity sales. A voluntary plan to control GHG emissions dating from 1997 is intensity-based and not based on absolute amounts, providing little incentive to utilities (Price 2005). Furthermore, under the current Japanese emission accounting system, electricity-related emissions are attributed to the electricity consumer rather than electricity producers. Safety regulation and the management of NPPs have been in the hands of the Ministry for the Economy and Trade (METI) which also promotes nuclear energy. There has therefore been a conflict of interest in terms of safety regulation.

Following the Fukushima accident, the question of checks and balances in respect of safety regulation within government and the power sector has been addressed. On 19 September 2012, the nuclear safety regulatory divisions of the Nuclear and Industrial Safety Agency was separated from METI and established as a strengthened external agency of the Ministry of the Environment. At the same time, the unbundling of the electricity generation and electricity transmission is being intensively discussed. This would induce a revolutionary change in the existing monopolised electricity system.

In terms of climate policy, a carbon tax was introduced on 1 October 2012. However, this is set at a relatively low rate (approximately $\$ 3 / \mathrm{tCO}_{2}$ ) and will be insufficient to induce sharp GHG emission reductions.

\section{Attitudes to nuclear power}

Before the Fukushima accident, the Conventional Basic Energy Plan had been developed by industry and energy experts belonging to the Advisory Committee for Natural Resources and Energy under the METI (METI, 2010).

However, after the Fukushima accident, a "national debate" has taken place in Japan. For the first time, public participation in the decision-making process has been attempted by providing "options" to the public. As part of the national debate process, scientific reviews and information were also provided to the public. Reviews of electricity costs (nuclear and renewables) and the costs of nuclear waste disposal (direct disposal/fast reactor) were made by the government and the discussion was summarised by Atomic Energy Commission and Central Environment Council (Energy and Environment Council, 2012a). 
The Cabinet Office Secretariat and the Energy and Environment Council (chaired by the Minister in charge of national strategy) have played a big role in the decision making process. They have generated the options presented to the public and have assessed the advantages and disadvantages of each.

On 29 June 2012, the Energy and Environment Council announced three options for a new energy policy to replace the 2010 goal of expanding nuclear power's share of national electricity generation from $30 \%$ to $50 \%$ by 2030 . The options were: to eliminate nuclear power altogether; to reduce dependence to $15 \%$ by 2030 ; or to reduce dependence to 20 $25 \%$.

On 22 August 2012, a government opinion poll on Japan's future energy policy showed that nearly $50 \%$ of respondents wanted to end Japan's nuclear power generation by 2030 , a far larger portion than those supporting more gradual reductions in nuclear power (Mainichi News, 2012). "Deliberative polling", a new and constructive way of researching public opinion, was also tried for the first time in Japanese policy making. A random, representative sample of the population was first polled on the issues at stake. After this baseline poll, selected members of the sample were invited to gather at a single place for a weekend in order to discuss the issues in depth. The outcome of the deliberative polling showed that the more information participants acquired about energy issues, the greater their support for reducing Japan's nuclear reliance to zero by 2030 (Bloomberg Businessweek, 2012).

Following the national debate, the Cabinet Office concluded that "at least, more than half support less nuclear dependent society". On 14 September 2012, the Energy and Environment Council officially announced a new Innovative Energy/Environmental Strategy which set out the following governmental decisions (Energy and Environment Council, 2012a):

1. A less nuclear dependent society (aiming at zero nuclear in the 2030s): Phase out of all plants after a 40 years life-time, no new construction, the re-start of existing plants only after strict safety checks, and a pending decision on high-level radioactive nuclear waste.

2. A green energy revolution: Promotion of energy saving ( $10 \%$ and $19 \%$ reductions in electricity and energy consumption respectively), renewable energy to increase by a factor of eight by 2030 compared to 2010 to reach $30 \%$ of electricity production.

3. Secure and stable energy supply: Utilisation of coal for base-load electricity, plus the promotion of gas fired generation.

4. Reform of the electricity system: unbundling electricity generation and transmission.

5. GHG reductions of $5-9 \%$ by 2020 from 1990 levels, and around $20 \%$ by 2030 . 
The future of these policies is not certain as it is possible that the current Democratic Party administration could be replaced by the opposition party after the next election. Importantly, the Innovative Energy/Environmental Strategy was not approved as a full Cabinet decision, which weakens its force. However, as a result of the current strong public sentiment against nuclear power, it would be extremely difficult to build new plant in the near future under any administration.

\section{What difference has Fukushima made?}

Five big changes have happened in Japan since the Fukushima-accident.

First, a consensus has been reached on the need for structural change in the energy sector leading towards a less nuclear-dependent society. On 1 November 2012, despite only two nuclear power generation units being in operation in Japan, there is no severe shortage of power supply. It would be very difficult to build new nuclear power plant in the near future.

Second, promotion of decentralised energy is progressing. A more progressive scheme for supporting decentralised energy was proposed by both policy makers and NGOs. The bill enabling the introduction of feed-in tariffs (FITs) successfully passed Congress on 26 August 2011. Under the FiT, solar power with a capacity more than $10 \mathrm{~kW}$ receives a tariff of $50 \mathrm{US}$ cents/kWh and wind turbines with a capacity more than $20 \mathrm{~kW}$ receive a tariff of $25 \mathrm{US}$ cents/kWh. These are relatively generous in international terms and are aimed at boosting investment in renewable energy.

Third, the system for regulating the safety of NPPs has changed. Due to strong criticism about conflicts of interests, the nuclear safety regulatory divisions of the Nuclear and Industrial Safety Agency were separated from METI and established as a strengthened external agency of the Ministry of the Environment. This will allow the new agency to develop a more independent and objective attitude towards nuclear power plant safety management.

Fourth, structural changes to the way in which the electricity grid is managed are anticipated. In the past, proposals to liberalise markets and restructure the management of the grid have been strongly objected to by the utility companies. However, some degree of unbundling of the electricity generation and electricity transmission will be unavoidable, and will have a large impact on the existing monopoly electricity suppliers.

Fifth, a large amount of energy conservation has been achieved. This has resulted from both stringent government policies and voluntary action. For example, electricity consumption in the Tokyo metropolitan area was reduced by $16 \%$ in July and August 2011 compared to the same months in the previous year (Yomiuri Shimbun, 2011). In the summer of 2012, almost 
same amount (15.6\%) of saving compared to the summer of 2010 was achieved in Tokyo (Energy and Environmental Council, 2012b). Industry reduced electricity demand and shifted the demand peak. Most manufacturing facilities conserved energy by lowering lighting levels and restricting the use of air conditioning. The car industry shifted operations from weekdays to the weekend. However, there is less certainty about the longer-term persistence of these actions without the introduction of appropriate incentives.

\section{Japan's response in the international arena}

In the context of the need for the radical reform of energy policy, the Innovative Energy/Environmental Strategy has been influenced to some degree by the argument that coal-fired power should be expanded to replace nuclear power and that Japan should reconsider its international commitments to GHG emissions reductions.

In 2008, domestic GHG emissions were $1.6 \%$ higher than in the Kyoto Protocol baseline year of 1990. However, this has been offset by a $5.1 \%$ decrease achieved through forestry and foreign credits purchased by the Government. In order to reach the $6 \%$ reduction required under the Kyoto Protocol target, another $2.5 \%$ decrease is therefore required. However, even if the economic recovery causes emissions to increase, and even if nuclear power plants do not operate, the situation does not require an immediate declaration of noncompliance with the Kyoto Protocol as long as the present level of energy conservation continues and foreign credits obtained by the industrial sector are taken into account. Following Fukushima, the $25 \%$ reduction target for 2020 promoted by former Prime Minister Hatoyama presents more difficulties. It is clear that the Government now wants to avoid stringent international commitments due to uncertainty about the energy mix and prospects for energy conservation. In addition, following Fukushima, the Japanese people appear to have become more inward-looking and less sensitive to global issues such as climate change. Climate scepticism has grown and has influenced both policymakers and the general public to some degree.

The current Innovative Energy/Environmental Strategy, stipulates a 5-9\% reduction in domestic GHG emissions by 2020 from the 1990 base year. The Japanese government faces challenges in both setting a GHG emission target which include international credit trading and forest sinks and in presenting its commitment to the wider world.

In conclusion, a very ambitious Japanese emissions reduction target cannot be expected, at least in the short time. The Fukushima accident has lowered the political priority attached to climate change mitigation. However, in the long term, fundamental institutional changes made following the Fukushima accident could help facilitate climate change mitigation action 
through the promotion of renewable energy and energy conservation. The political power of the incumbent utility companies has also decreased which will change the dynamics of the energy/climate policy making process.

\section{The UK post-Fukushima: the dog that did not bark}

\section{Patterns of energy supply and demand in the UK}

The UK's trade balance in energy is changing rapidly and is driving a new debate about energy security. The UK became a net importer of gas in 2004 and a net importer of crude oil in 2006 (DECC, 2012). Dependence on gas imports has led to perceptions of vulnerability that have raised the political profile of the energy security issue (Wicks, 2009). This has been exacerbated by a perceived risk of the "lights going out" due to a capacity pinch in the electricity sector around 2015. This is due to older nuclear plants closing and some coal stations shutting down under the requirements of the EU Large Combustion Plant Directive. New nuclear is perceived as part of the policy response to the UK's changing energy balance.

\section{UK energy and climate policy}

The UK's energy and climate policy rests on three foundations: environmental concerns, notably climate change; energy security; and "affordability". Under the Climate Change Act (CCA) 2008, the UK is legally committed to reducing GHG emissions by $80 \%$ by 2050 . In addition, three consecutive legally binding five-year budgets must be in place at any one time. The 3rd carbon budget for 2018-2022 requires a 34\% reduction in GHG emissions relative to 1990 . In 2011 , a $4^{\text {th }}$ carbon budget, which would see emissions falling by $50 \%$ by 2023-27, was legislated.

The Government believes that a radical decarbonisation of the electricity sector is needed to meet climate policy goals (DECC, 2011a). The Committee on Climate Change envisages the carbon intensity of electricity generation falling from today's level of around $500 \mathrm{~g} \mathrm{CO}_{2} / \mathrm{kWh}$ to under $300 \mathrm{~g} / \mathrm{kWh}$ by 2020 and below $100 \mathrm{~g} / \mathrm{kWh}$ by 2030 (Committee on Climate Change, 2011). Gas-fired generation, unless associated with carbon capture and storage (CCS), can have little role by 2030 under this scenario. However, a debate about the role of natural gas in the electricity mix has been developing. The Government has proposed that gas plants without CCS can be allowed to operate until 2045. It is argued by others that this undermines the 2030 electric decarbonisation objective (HC Energy and Climate Change Committee, 2012). 
The UK is pursuing all possible low carbon electricity generation options. There are plans to demonstrate CCS at scale at four sites. Renewable electricity is being promoted, prompted by the requirements of the EU Renewable Energy Directive which requires the UK to source $15 \%$ of final energy demand from renewables by 2020 . The UK is planning for renewables to meet $30 \%$ of electricity generation needs by 2020 (DECC, 2011b). The main renewable energy technologies will be onshore wind, offshore wind and biomass power.

Nuclear new build is being actively promoted with three consortia having expressed ambitions to build $16 \mathrm{GW}$ of new plant. The original plan was that the first plant would come on line in late 2017 but the timetable has slipped and neither the Government nor the developers now refer to target dates. This government and the previous one have stated that there will be no public subsidy for nuclear and work commissioned by government appears to show that nuclear is the cheapest of the low carbon options (Mott McDonald, 2011). However, it has been argued that actual costs, allowing for the risk of failing to build to time and cost, are higher and that public support would be necessary (Reuters, 2012). The UK no longer has the domestic capability to design and build nuclear stations. Although three consortia have been developing plans for new build, business support has been eroding. In September 2011, Scottish and Southern Energy withdrew from NuGen, a joint venture between themselves, GDF Suez and Iberdrola, saying that "its resources are better deployed on business activities and technologies where it has the greatest knowledge and experience". The German companies RWE and E.ON, both dealing with a nuclear phase-out in their home territory, withdrew from the Horizon Nuclear Power consortium in March 2012. Their share was bought by the Japanese company, Hitachi, in October 2012. Blocked nuclear ambitions in both Germany and Japan have thus affected the UK electricity sector. The international consequences of the German Energiewende are further demonstrated by the withdrawal of Siemens from the nuclear business in 2011.

The French EDF/Centrica consortium which plans to build the first of the new reactors has retained its public commitment to new build. However, Centrica has publicly voiced concerns about the "business case". EDF has indicated that it retains "confidence in our collective ability" (that of business and Government) to deliver nuclear new build but, in evidence to a Parliamentary Inquiry, has expressed concern about some aspects of the proposed reform of electricity markets (see below) needed to provide investor confidence.

There has been policy continuity in the UK with both the current Coalition Government and the previous Government actively promoting nuclear power. But the junior partners in the current Coalition, the Liberal Democrats, went into the last election opposed to nuclear. 
However, the Liberal Democrats have supported the Coalition Agreement on nuclear postFukushima.

\section{Institutional Arrangements}

The Government has taken a number of steps to facilitate nuclear new build. Changes to the spatial planning system and a new system of National Policy Statements mean that generic policy issues, such as the relative merits of nuclear or renewables, will no longer be within the scope of local planning inquiries. An Office for Nuclear Development (OND) has been established within the Department of Energy and Climate Change and a stream-lined Generic Design Assessment (GDA) process for new reactor types has been introduced (DECC, 2011c). The Westinghouse AP1000 reactor and the Areva European Pressurised Water Reactor (EPR) have now received interim design acceptance confirmation under the GDA process.

However, the biggest change relates to the design of electricity markets. Low carbon generation is capital intensive and is exposed to high levels of risk in volatile wholesale electricity markets. Under Electricity Market Reform (EMR), long-term contracts for low carbon generation will be introduced (DECC, 2011d). The current Renewables Obligation will be superseded by a system of "feed-in tariffs (FiTs) through contracts for differences (CfDs)". All low carbon generation, including nuclear, will continue to participate in the wholesale electricity market, but will be paid the difference between a contracted strike price and a reference price in the wholesale market.

A draft Energy Bill aimed at implementing EMR was heavily criticised by a Parliamentary Committee during pre-legislative scrutiny (HC Energy and Climate Change Committee, 2012). Among the key issues were the lack of a tangible counter-party for the CfDs, which most witnesses construed as a reversal of Government policy, and compatibility with EU state aid rules if nuclear were to receive a subsidy.

As part of EMR, a "carbon price floor" has been legislated to counteract low and volatile carbon prices in the EU ETS. The Government plans to set a target carbon price, rising to $£ 20 /$ tonne $\mathrm{CO}_{2}$ by 2020 and $£ 70 /$ tonne by 2030 . Fuels for electricity generation will be taxed according to the difference between the target price and forward EU ETS prices. This will benefit both existing and new nuclear plant.

Nuclear safety is currently regulated by an Office of Nuclear Regulation headed by the Chief Inspector of Nuclear Installations. For historic reasons, ONR is currently part of the Health and Safety Executive, an independent regulator responsible for workplace health and safety. 
It is sponsored by the Department of Work and Pensions. The Government plans to establish ONR as a separate statutory body.

The Government was prompt in commissioning a report by the Chief Inspector of Nuclear Installations (the "Weightman Review") on the implications of Fukushima for the UK (HM Chief Inspector of Nuclear Installations, 2011). This was not a fundamental review of nuclear and its place in the UK energy mix, but a narrower technical review of UK nuclear safety arrangements. It concluded that there was "no reason for curtailing the operation of nuclear power plants or other nuclear facilities in the UK".

The review argued that the UK's nuclear regulator operates independently of industry and government, and that the institutional weakness now being addressed by the Japanese government is not present in the UK. It noted that the Japanese earthquake/ tsunami were "far beyond the most extreme natural events that the UK would be expected to experience". The review recommended improving safety arrangements, such as ensuring that "safety cases for new sites for multiple reactors adequately demonstrate the capability for dealing with multiple serious concurrent events induced by extreme off-site hazards". The recommendations were essentially incremental. There was little public debate about the Weightman report although it was claimed by some NGOs that it was "a rushed report.... designed with one objective - to give the green light to a new generation of nuclear power stations, irrespective of the safety, environmental or rising financial costs" (Greenpeace, 2011).

\section{Attitudes to nuclear power}

Public attitudes have been studied systematically since the Government started to promote nuclear in the mid-2000s (Pidgeon et al, 2008; Bickerstaff et al., 2008). Polling conducted in the summer of 2011 (Ipsos-Mori, 2011) shows that support for nuclear power had weakened post-Fukushima but that it was still, on balance, positive. This helps explain the low level of public debate. $68 \%$ of people agreed that "Britain needs a mix of energy sources to ensure a reliable supply of electricity, including nuclear power and renewable energy sources". $36 \%$ supported new build as opposed to $28 \%$ who opposed. Another survey (Populus, 2011) highlighted the strong gender differences on nuclear power (men being more supportive than women), which Fukushima appears to have accentuated.

Recent UK public opinion on nuclear power has been characterised as "reluctant acceptance" (Corner et al., 2011). If nuclear power is characterised as part of a response to problems such as climate change, and if it is part of a set of solutions that includes renewable energy, then it appears to be acceptable to a majority of the population. 
Against this background, environmental NGOs, although opposed to nuclear power, have not prioritised it as a campaigning issue. Recent Greenpeace campaigns have been directed primarily at fossil fuels including preventing the construction of new coal-fired power stations without CCS and a "go beyond oil" campaign targeting Arctic drilling for oil (Greenpeace UK, no date).

The attitudes of people in communities that host nuclear power are also vital. Here, support appears to be solid (Parkhill et al, 2010). Members of Parliament representing constituencies in which nuclear power stations are sited tend to support new build on economic and employment grounds (e.g. Bridgwater Mercury, 2009). As any new build will take place at existing sites, decisive local opposition is unlikely to emerge.

\section{What difference has Fukushima made?}

Fukushima appears to have had little direct effect on nuclear prospects in the UK. Public debate has been muted, NGOs have been relatively silent and Government promotion of nuclear power has continued. The biggest obstacle to new build appears to be the ability of developers to make a business case in the context of a poor construction record in other parts of Europe (France, Finland) and complex and ambitious Electricity Market Reform arrangements. Here, Fukushima has had an indirect effect through the withdrawal of several key players (RWE/E.ON/Scottish and Southern/Siemens) from the nuclear arena. The prospects for new build in the UK remain credible but are more fragile than they were in early 2011.

\section{The UK's response in the international arena}

The UK strongly supports a legally binding international agreement on climate change. This position is backed by ambitious commitments at the domestic level. Decarbonisation of the electricity sector over the next 20 years will play a central role in delivering this ambition. Nuclear power plays a significant role in many electricity decarbonisation scenarios out to 2030 (e.g. CCC, 2011), although the need for nuclear is disputed (WWF-UK, 2011). The UK will continue to take an active role in international climate negotiations, alongside the active promotion of nuclear power.

\section{Germany: Green energy for climate change}

\section{Patterns of energy supply and demand in Germany}

Germany has seen significant changes in its electricity supply over recent years. Due to active policies, the renewable share of electricity generation has increased from $5 \%$ in 1990 
to $25 \%$ in the first half of 2012 and is still rapidly increasing. Political targets for 2020 range between some 35\% in the National Renewable Energy Action Plan (NREAP) and over 50\% according to the targets of individual Länder (see Lechtenböhmer \& Samadi 2012). This success has compensated for declining fossil production and stabilised the proportion of domestic primary energy demand supplied from indigenous sources at slightly less than $30 \%$ since the late 1990s (AG Energiebilanzen 2011).

\section{The energy concept 2010: Low carbon strategy and a nuclear revival}

Climate policy has been high on the German political agenda since it surfaced in the international political arena in the late 1980s. In 1990, the first of a series of parliamentary Enquête-Commissions generated important insights into the topic and provided the rationale for most of the current climate change targets. Subsequently, scenarios describing a long term sustainable and low carbon German energy system were developed (e.g. Wuppertal Institut 1995). An Enquête Commission on Sustainable Energy Supply analysed several long term low-carbon energy scenarios for Germany which covered the expansion of nuclear, a fossil pathway and a renewable pathway (Hennicke 2004).

Following G8 decisions in Heiligendamm (2007) and with the anticipation of success at the UN Framework Convention on Climate Change (UNFCCC) Conference of the Parties in Copenhagen in 2009 , the international community focused on long term perspectives. Various stakeholders in Germany proposed long term low carbon energy scenarios (see Lechtenböhmer et al. 2010 for an overview). In line with official policy at the time, which was to phase out nuclear, all but one of these scenarios rejected nuclear, but differed in their ambition regarding energy efficiency, renewable expansion and the role of fossil fuels.

Building on this debate the Christian-Democrat/Liberal coalition that took over the Federal Government in fall 2009 prepared a new energy concept. This concept envisaged ambitious GHG emission reduction targets of 80 to $95 \%$ for the period up to 2050 and an increase in renewable energy to $80 \%$ of electricity production and $60 \%$ of total primary energy supply (German Government 2010). Its main political purpose, however, was to justify the roll-back in nuclear policy that the governing parties had announced. Despite strong public opposition, the government pushed its energy concept through Parliament, prolonging the lifetimes of existing NPPs by eight to 14 years (BMU, MUKE, 2011, p6). According to a poll conducted for the Ministry of Environment $63 \%$ of the population were against nuclear lifetime expansion and only $25 \%$ were in favour. The level of support for nuclear was less than in previous polls in 2006 and 2008 (BMU, UBA 2010, 45) 


\section{A political tsunami triggered the German nuclear "U-turn"}

Against the background of a continuing and highly controversial debate on the lifetime extension of NPPs, the catastrophe at the Fukushima NPP resonated in German public debate. This forced the government to implement an immediate U-turn on nuclear policy. Wittneben (2011) proposed five factors that led to this strong reaction. Most evident among these are: a) imminent elections; and b) very intense reporting of nuclear issues in the media, which was in turn enhanced by the elections. The others reasons are: c) a feeling of close cultural proximity to the Japanese ${ }^{1}$; d) the history of nuclear resistance; and, probably most important, e) an increasing trust in renewable technologies.

a/b) As the continuing opposition against their very recent lifetime extension was strongly intensified by Fukushima, Christian Democrat leaders identified nuclear as a major political problem. They feared that it would cost them votes in the coming elections and would, in the long term, close the option of going into coalition with the Greens who are strictly antinuclear (Luhmann 2011). As a consequence, only one week after the accident, Chancellor Merkel imposed a three month moratorium on operations at eight of the oldest NPPs, installed an independent Ethics Commission on the further role of nuclear in Germany and asked the Commission on Reactor Safety to check nuclear safety standards.

d) The existence of a strong anti-nuclear movement in Germany had led to the foundation of a Green party in the early 1980s and was strengthened by the 1986 Chernobyl disaster (Renn 2011, 3ff). The first red-green Federal Government elected in 1998 made a nuclear phase out official policy. In 2000 , a phase-out contract with the electricity industry was concluded with formal legal regulations following in 2002. The so called "nuclear consensus" guaranteed 32 operating years for NPPs before they had to be decommissioned. Although by 2010 only two commercial NPPs had been decommissioned, and only one of these had been decommissioned as a result of the phase-out policy this laid important foundations for the current energy policy (cp. Jahn, Korolczuck 2012).

${ }^{1}$ This argument has not been very prominent in the general discussion and is not further taken into account here. 
e) As polls show, Germans never liked nuclear energy but many people were inclined to accept the technology as a necessity. General attitudes towards nuclear have changed only slightly due to Fukushima. What really has changed in public opinion has been the perception that nuclear is no longer needed as there are alternatives. In $1991,60 \%$ of the population believed that nuclear power would be one of the major energy sources of the future 30 years ahead while only $26 \%$ whished nuclear to be a major source. By 2004 the number of people who still believed that nuclear would play a major role had declined by more than half to $26 \%$ with only $19 \%$ being in favour (Allensbach 2004 , slide 20 ). This change in expectations about the need for nuclear was also the main argument for the Ethics Commission ${ }^{2}$ when it rejected further use of nuclear energy in Germany (Ethics Commission for a Safe Energy Supply, 2011). The Commission found that Germany had less risky alternatives and should therefore exit from the technology within a decade. As a consequence between June and July 2011 several laws on the "Energiewende" (energy turnaround) were decided with broad political support. The provisions will lead to the final closure of the eight NPPs already taken out of operation and set firm termination dates for the licenses of the remaining nine NPPs, the last of which will cease operation by the end of 2022

This more or less takes Germany back to the former phase-out policy adopted by the RedGreen coalition.

The political significance of the post-Fukushima decisions is that all the major political parties openly support a nuclear phase-out. This sends a clear signal to the electricity industry that, unlike previously, there is now no prospect of prolonging nuclear operations.

\footnotetext{
${ }^{2}$ The commission was installed in March 2011 as a consequence to the Fukushima event in order to analyse the ethical foundations of nuclear energy in Germany. (For more information including teh final report in English see: http://www.bundesregierung.de/Content/DE/Artikel/2011/05/2011-05-30-berichtethikkommission.html)
} 


\section{Blown by the wind: Nuclear replaced by renewable electricity}

The rapid phase-out decision of March 2011 has raised concerns about Germany's ability to secure its electricity supply. However, data shows that Germany was able to compensate for nuclear. In 2011, Germany was neither a net importer of electricity nor did it increase its domestic fossil electricity generation. In 2011, the shut-down of eight of the 17 NPPs reduced electricity generation by about 32 TWh compared to $2010.60 \%$ of the missing generation was substituted by increased renewable generation, while decreased net exports of electricity accounted for the remainder. However, Germany still had net exports of about 5 TWh in 2011. Taking into account a slight reduction in domestic electricity demand, electricity generation from fossil fuels decreased by some 3 TWh. (AG Energiebilanzen, 2011a, 2011b; BDEW 2011, Lechtenböhmer \& Samadi 2012)

According to recent projections, Germany has a realistic chance of replacing nuclear generation fully with additional renewable energy by 2022, compared to a 2010 baseline. If official targets for electricity savings are met, renewables will then account for more than $50 \%$ of German electricity and $\mathrm{CO}_{2}$ emissions could be reduced by more than $50 \%$ from1990 levels (Lechtenböhmer and Samadi, 2012).

\section{Renewable energies for international climate change and green growth}

Germany has been a strong supporter of international climate policy since the beginning, at the EU-level, in the UNFCCC and in the G8. With its energy concept, the German government decided on long term national GHG-reduction targets, which would have been in line with a strengthening of the EU-target for 2020 to a $30 \%$ reduction in emissions compared to 1990. The German targets have not been changed, either as a consequence of nuclear phase-out-decision or because of the severe problems that have been encountered in implementing CCS technology.

An important reason for this is the success, partly unexpected, of renewable electricity production which has also generated a high level of new jobs and income both from domestic investment and from the export of technology. A "critical mass" appears to have been reached in the sector.

Against this background, the concept of green-growth has become highly politically relevant. From a German perspective, it would be attractive if other countries followed the same path. It is believed that this would both help other countries economically and, at the same time, generate attractive export opportunities for German technology suppliers. Therefore Germany will not only support further ambitious climate policy targets but will also help to develop concrete strategies that focus on different forms of technology cooperation and 
mitigation action. At the EU level, debate over the extension of the Renewable Energy Directive will be important for Germany. With a potential overachievement of national 2020 targets, Germany is likely to push for ambitious targets beyond 2020. Internationally, there is firm German support for the DESERTEC concept which would establish energy interconnections between North Africa and Europe. In addition, Germany strongly supports the new International Renewable Energy Agency (IRENA) and the new South African Action on Renewables Initiative. Germany also had the ambition of hosting the UN Green Climate Fund (German Government, 2011).

\section{Conclusions}

The Fukushima accident has triggered far-reaching changes in climate and energy policies not only in Japan but in countries on the other side of the world. In this final section, we summarise the responses in Japan, the UK and Germany, considering differences and commonalities as well as some cross-country lessons.

Until 2011, all three governments had planned to increase the role of nuclear. The Fukushima accident, though it did not affect Germany directly, precipitated a U-turn in energy policy. Against a challenging political background, the government shut older nuclear plants immediately and enacted plans to close the rest by 2022. Japan shut many nuclear plants immediately, facing consequent power shortages, but took far longer to announce a nuclear phase-out, albeit one that will be much slower than in Germany with the last plant coming off-line in 2039 according to current plans. Following a pre-emptive review of safety regulation and a relatively low level of public concern ("it couldn't happen here"), the UK is continuing with plans for nuclear new build. Any question-marks about future developments relate to market conditions and the financial framework for nuclear power which are, at best, affected indirectly by the Fukushima accident. In September 2012, A business deal that links all three countries was concluded when Hitachi, whose future role in the Japanese nuclear sector has been blocked, bought the interest of two German utilities, RWE and E.ON in Horizon Power which is planning nuclear new build in the UK.

Germany has reinforced its ambitions for renewable energy, building on its existing success in transforming its electricity system. This will directly affect Germany's neighbours. The UK had already planned to scale up renewable energy starting from a very low base although, unlike in Germany, there is no plan for renewables to dominate electricity generation. The view in UK policy-making circles has been that nuclear would be "reluctantly accepted" by the public as a long as it was part of a package that included parallel support for renewables. The situation in Japan is far less clear. Traditional resistance to renewables among 
established interests in the electricity sector and government is now balanced by a wider interest across society. The ensuing tensions have yet to be resolved.

Table 1 presents, at a very high level, a number of indicators which suggest reasons for the very different positions the three countries have taken.

Table 1: Indicators of propensity to support/reject nuclear power

\begin{tabular}{llll}
\hline & Japan & Germany & UK \\
\hline Climate change policy & $\mathrm{H}$ & $\mathrm{M}$ & $\mathrm{H}$ \\
Energy security needs & $\mathrm{H}$ & $\mathrm{M}$ & $\mathrm{L}$ \\
Market liberalisation & $\mathrm{L}$ & $\mathrm{H}$ & $\mathrm{L}$ \\
Interconnected electricity system & $\mathrm{L}$ & $\mathrm{H}$ & $\mathrm{H}$ \\
Independence of regulatory scrutiny & $\mathrm{L}$ & $\mathrm{H}$ & $\mathrm{L}$ \\
$\begin{array}{l}\text { Sensitivity to nuclear accidents, weapons siting } \\
\text { etc. }\end{array}$ & $\mathrm{H}$ & $\mathrm{N}$ & $\mathrm{Y}$ \\
Nuclear weapons capability & $\mathrm{N}$ & $\mathrm{Y}$ & $\mathrm{N}$ \\
Existence of plans for nuclear phase-out & & $\mathrm{H}$ & $\mathrm{M}$ \\
Strength of anti-nuclear movement & $\mathrm{Y}$ & $\mathrm{H}$ & $\mathrm{L}$ \\
Perceived availability of alternatives & $\mathrm{L}$ &
\end{tabular}

Notes: $\mathrm{Y}=$ yes; $\mathrm{N}=$ no; $\mathrm{H}=$ high; $\mathrm{M}=$ medium; $\mathrm{L}=$ low

Source: subjective view of the authors

Germany and Japan have decided to phase out nuclear power: the UK has not. The underlying reason appears to be a lower level of anxiety about nuclear risks in the UK which is the only nuclear weapons state and where there appears to be public confidence in regulatory institutions. In addition, there appears to be a broad belief that events such as the 2011 tsunami are inconceivable given the UK's geography. Environmental NGOs have not prioritised opposition to nuclear new build and any obstacles appear to be in the commercial rather than the public acceptability domain.

The difference between Germany and Japan lies in the speed and decisiveness of the response. In spite of the fact that the tsunami occurred thousands of miles away, Germany was the first to propose a nuclear phase-out within 10 years, while Japan took much longer to agree a phase-out which will take 25-30 years. Germany could act quickly because of the extent of prior policy effort on the alternatives, notably renewable energy for which ambitious 
targets already existed. In addition, Germany is firmly embedded in the wider European electricity market and could re-balance domestic production, imports and exports to compensate for nuclear plants going off-line.

Although it was Japan that was directly affected by the Fukushima, the country's dilemma was more acute. Plant shutdowns have stimulated the need for voluntary reductions in electricity demand; imports of natural gas have risen to help compensate for lost nuclear output; and already challenging climate change targets have been dropped. Although Japan's response has necessarily been slower in terms of energy policy change, the changes run far deeper and are of perhaps historical significance. Electricity markets arrangements are being revised; regulatory powers have been transferred to remove conflicts of interest; and the balance of ambition for nuclear and renewable energy has been fundamentally altered. The events and the response may have changed forever the Japanese public's relationship with technical elites.

The impacts on international climate policy are less clear. The German and UK governments continue to support ambitious international climate policies as part of a broader European effort. If anything, the German position may become stronger as it seeks to export the new renewables solutions proposed as part of its energy policy U-turn. On the other hand, there is an emerging policy debate in the UK about the perceived cost of renewable energy and its impact on energy bills. The government has not so far changed policy although the Chancellor of the Exchequer has flagged concerns about impacts on UK competitiveness. Japan had already announced that it would not support the continuation of the Kyoto Protocol even before the Fukushima accident. The Japanese government will be reluctant to change this position on the grounds of policy consistency. However environmental NGOs are demanding a change of the negotiating position on the grounds that Japan will not be significantly disadvantaged following the Durban agreement in which all major economies will commit to some GHG emission reductions in the near future. Longer term Japanese policy is deeply uncertain as fears about climate change have been replaced by more immediate concerns following the tsunami and Fukushima accident.

The case studies demonstrate that trust and local agreement are crucial for low carbon electricity. Well-designed institutional arrangements for regulating energy technologies and markets appear to be critical. The lack of separation of responsibilities for promoting and regulating nuclear power was a fundamental institutional weakness in Japan, now recognised by the Japanese government. This may not only have contributed to the severity of the Fukushima accident through compromised safety standards, it may have further undermined public trust in Japan's energy companies and institutions. In the UK, the 
capacity to commission a rapid, independent review of safety arrangements helped to prevent a decisive shift in public opinion away from nuclear.

The question of trust extends more widely. In the UK, nuclear had been promoted by the government as part of the solution to climate change alongside renewable energy. The "nuclear and renewables" policy message, rather than "nuclear versus renewables", appears to have generated acceptance of the general policy thrust. Trust is also important at the local level. In the UK, local communities, accustomed to living alongside nuclear plants, have supported new build at existing sites. There has been no attempt to develop nuclear power at greenfield sites. In Japan local resistance is the reason why nuclear power plants shut down for inspection are currently not being reconnected to the grid.

Local considerations and sensitivities to energy investments are critical. Germany could require considerable investment in electricity transmission capacity to further its renewable ambitions. The German regulator has already expressed concern about whether this investment can be made in a timely way given possible resistance from local communities. In the UK, there has been considerable resistance to onshore wind at certain sites, driving utilities to make more expensive offshore investments.

Finally, both Germany and Japan have demonstrated the capacity to turn round energy policy very quickly. Both have coped, although with some distress in Japan, with the loss of considerable volumes of electricity generation output. In Japan, "business-as-usual" in terms of electricity consumption was not an option. Here, the possibility of saving significant amounts of energy very quickly in an emergency has been demonstrated. It is unlikely that these patterns of consumption will be sustained but there are lessons to be learned about the possibility of decoupling economic activity, energy use and $\mathrm{CO}_{2}$ emissions. 


\section{References}

AG Energiebilanzen, 2011a. Stromerzeugung nach Energieträgern von 1990 bis 2010 (in TWh) Deutschland insgesamt, http://www.ag-energiebilanzen.de/viewpage.php?idpage=65 AG Energiebilanzen, 2011b. Energieverbrauch sinkt 2011 kräftig, http://www.agenergiebilanzen.de/viewpage. php?idpage $=62$.

AG Energiebilanzen, 2011c. Primärenergiegewinnung Deutschland, http://www.agenergiebilanzen.de/viewpage.php?idpage $=66$

Allensbach (2004): Studie Umwelt 2004. Gesamtergebnisse im Überblick, Institut für Demoskopie Allensbach. http://www.ifdallensbach.de/uploads/tx_studies/6572_Umwelt_2004.pdf American Daily Herald, 2011. Japan Reconsidering Nuclear Energy, Wednesday, 14 December 2011 05:55 , Hiroshi Nomaki http://www.americandailyherald.com/201112141067/asia/japan-reconsidering-nuclearenergy

BDEW, 2011. Entwicklungen in der Stromwirtschaft 2011, Presentation by Michael Nickel during the meeting of the Arbeitsgemeinschaft Energiebilanzen on 16 December 2011. Bickerstaff, K. et al., 2008. Reframing nuclear power in the UK energy debate: nuclear power, climate change mitigation and radioactive waste. Public Understanding of Science, vol. 17 , no. 2 , pp 145-169

Bloomberg Businessweek, 2012. Japan Citizens Favour Zero Nuclear in Debate Over Energy Options, 22 August, http://www.businessweek.com/news/2012-08-22/japan-finds-47percent-of-citizens-support-zero-nuclear-power-option, last accessed 11 November 2012 BMU (Bundesministerium für Umwelt, Naturschutz und Reaktorsicherheit), MUKE (Ministerium für Umwelt, Klima, Energiewirtschaft, Baden-Württemberg) , 2011. Regulatory implications of the Fukushima Dai-ichi NPP accident, IRRS follow-up mission Germany 2011, Supplement on the Advance Reference Material (ARM)

BMU (Bundesministerium für Umwelt, Naturschutz und Reaktorsicherheit), UBA (Umweltbundesamt), 2010: Umweltbewusstsein in Deutschland 2010. Ergebnisse einer repräsentativen Bevölkerungsumfrage

Bridgwater Mercury, 2009. New Hinkley Point power station gets Government backing, 10 November.

http://www.bridgwatermercury.co.uk/news/4730097.New_Hinkley_Point_power_station_gets _Government_backing/?ref=mr 
Committee on Climate Change, 2011. The Renewable Energy Review, Committee on Climate Change, London, May

Corner, A. et al., 2011. Nuclear power, climate change and energy security: Exploring British public attitudes, Energy Policy, Vol 39 (9), pp 4823-4833

DECC, 2010. Gas Security of Supply: A policy statement from the Department of Energy and Climate Change, London, 2010

DECC (Department of Energy and Climate Change), 2011a. The Carbon Plan: Delivering our low carbon future, London, December

DECC (Department of Energy and Climate Change), 2011b. The Renewable Energy Roadmap, London, July

DECC (Department of Energy and Climate Change), 2011c. National Policy Statement for Nuclear Power Generation (EN-6), London, July

DECC (Department of Energy and Climate Change), 2011d. Planning our electric future: a White Paper for secure, affordable and low-carbon electricity, London, July

DECC (Department of Energy and Climate Change), 2012. Digest of United Kingdom Energy Statistics, TSO, London

The Energy and Environment Council, 2012a. Innovative Energy/Environmental Strategy, Sep.14, 2012. (in Japanese)

http://www.npu.go.jp/policy/policy09/pdf/20120914/20120914_1.pdf

The Energy and Environment Council, 2012b. Report of the Demand and Supply Verification committee (draft), Oct. 2012. (in Japanese)

http://www.npu.go.jp/policy/policy09/pdf/20121030/shiryo2-2.pdf

Ethics Commission for a Safe Energy Supply, 2011. Germany's energy transition - A collective project for the future, Berlin, 30th May 2011, http://www.bundesregierung.de/Content/DE/_Anlagen/2011/05/2011-05-30abschlussbericht-ethikkommission_en, property=publicationFile.pdf. German Government, 2010. Energy Concept for an Environmentally Sound, Reliable and Affordable Energy Supply, http://www.bmu.de/files/english/pdf/application/pdf/energiekonzept_bundesregierung_en.pdf. German Government, 2011. Deutschland wirbt um neuen Klimafonds, 08.12.2011 http://www.bundesregierung.de/Content/DE/Artikel/2011/12/2011-12-08-Klimafonds.html 
Greenpeace UK, 2011. Weightman report - a rushed job before lessons are learned from Fukushima, London 11 October, http://www.greenpeace.org.uk/media/pressreleases/weightman-report-rushed-job-lessons-are-learned-fukushima-20111011, last accessed 20 August 2012

Greenpeace UK, no date. Go beyond oil, http://www.greenpeace.org.uk/oil, last accessed 20 August 2012

Hennicke, P., 2004. Scenarios for a robust policy mix: the final report of the German study commission on sustainable energy supply. Energy Policy Volume: 32, Issue: 15, Pages: 1673-1678, DOI: 10.1016/S0301-4215(03)00163-0

HC (House of Commons) Energy and Climate Change Committee, 2012. Draft Energy Bill: Pre-legislative Scrutiny - First Report of Session 2012-13, HC257-1, London HM Chief Inspector of Nuclear Installations, 2011. Japanese earthquake and tsunami: Implications for the UK nuclear industry: Final Report, Office of Nuclear Regulation, September Hoedt, ten, Rudolf, 2012. Japan's "Nuclear Village": too big to fail?, European Energy Review, Report 6 February 2012

International Energy Agency, 2012. Energy Statistics of OECD Countries (Edition: 2012). ESDS International, University of Manchester. DOI: http://dx.doi.org/10.5257/iea/eso/2012 Ipsos-MORI, 2011. Nuclear response June 2011: (Nuclear Issues Tracking), Ipsos MORI/10044621-01, http://www.ipsos-mori.com/Assets/Docs/Polls/ipsos-mori-nia-nuclear-powertopline-august-2011.pdf

Lechtenböhmer, S. Gröne, M.-C., Acuner, E., Samadi, S, 2010. Review of Long Term Visions and Strategies for a Sustainable Germany. German Country Brief to the LCS-R Network Annual Meeting, Berlin 20-21 September 2010, Wuppertal Lechtenböhmer, S., Samadi, A., 2012 Blown by the Wind. Replacing Nuclear Power in German Electricity Generation, Environmental Science \& Policy, article in press, http://dx.doi.org/10.1016/j.envsci.2012.09.003

Luhmann, H.-J., 2011. 100 Prozent Strom aus erneuerbaren Quellen in Deutschland, GAIA 20/4 (2011): 217 | www.oekom.de/gaia

Mainichi News, 2012. Gov't poll shows about 50\% want to end Japan's nuclear reliance, Aug. 22, 2012. (in English) http://mainichi.jp/english/english/newsselect/news/20120822p2g00m0dm029000c.html 
METI, 2006. General description of the RPS, Oct, 2006. (in Japanese), http://www.meti.go.jp/committee/materials/downloadfiles/g61108c06j.pdf METI, 2010. The Strategic Energy Plan of Japan, Tokyo, June. http://www.meti.go.jp/english/press/data/pdf/20100618_08a.pdf, last accessed 11 November 2012

Otway HJ et al., 1978. Nuclear power: The question of public acceptance, Futures, Vol 10 (2), pp109-118, http://dx.doi.org/10.1016/0016-3287(78)90065-4

Parkhill, K. et al., 2010. From the familiar to the extraordinary: local residents' perceptions of risk when living with nuclear power in the UK, Transactions of the Institute of British Geographers, Vol 35, No 1, pp 39-58, January

Pidgeon NF et al., 2008. Climate change or nuclear power-No thanks! A quantitative study of public perceptions and risk framing in Britain, Global Environmental Change, pp 69-85, http://dx.doi.org/10.1016/j.gloenvcha.2007.09.005,

Populus, 2011. Attitudes on nuclear power, British Science Association, http://www.populus.co.uk/Poll/Attitudes-on-nuclear-power/

Price, L. 2005. Voluntary Agreements for Energy Efficiency or GHG Emissions Reduction in Industry: An Assessment of Programs Around the World LBNL-58138, Proceedings of the 2005 ACEEE Summer Study on Energy Efficiency in Industry http://ies.lbl.gov/iespubs/58138.pdf

Renn, O., 2011. Wissen und Moral - Stadien der Risikowahrnehmung Essay, APuZ 46$47 / 2011$

Reuters, 2012. UK nuclear build requires taxpayer rescue - Citi, May 8 2012, http://www.reuters.com/article/2012/05/08/nuclear-britain-edf-idUSL5E8G8FQ620120508, last accessed 20 August 2012

Rossnagel, A. and A. Hentschel, 2010. Rechtsgutachten zur Zustimmungsbedürftigkeit des elften Änderungsgesetzes zum Atomgesetz im Auftrag der Bundestagsfraktion Bündnis 90/Die Grünen und der Fraktion Bündnis 90/Die Grünen des Landtags Baden-Württemberg, Kassel, 15. Oktober 2010

Stohl A. et al., 2011. Xenon-133 and caesium-137 releases into the atmosphere from the Fukushima Dai-ichi nuclear power plant: determination of the source term, atmospheric dispersion, and deposition. Manuscript prepared for Atmos. Chem. Phys. Date: 8 October 2011 
Wall Street Journal, 2011. In Japan, Provocative Case for Staying Nuclear: Some Say Bombs' Potential as Deterrent Argues for Keeping Power Plants Online, October 28, 2011. http://online.wsj.com/article/SB10001424052970203658804576638392537430156.html Wicks, M., 2009. Energy Security: A national challenge in a changing world, Department of Energy and Climate Change, London

Wittneben, B. B. F., 2011. The impact of the Fukushima nuclear accident on European energy policy, Environmental Science \& Policy, Vol 15, pp. 1 - 3.

Wuppertal Institut, 2005.Zukunftsfähiges Deutschland (published in English as: Sachs, W., Loske, R., Linz, M., 2006, Greening the North. ZEB-Publications \& Wuppertal Institut WWF-UK, 2011, Positive Energy: how renewable electricity can transform the UK by 2030, WWF-UK, Godalming,

http://assets.wwf.org.uk/downloads/positive_energy_final_designed.pdf Yomiuri Shimbun, 2011, Electricity Saving in Tokyo, Dec.7, 2011. http://www.yomiuri.co.jp/job/news/20111006-OYT8T00858.htm 